\title{
HbsAg and antiHCV seroprevalence in an Eastern province of Turkey
}

\section{Türrkiye"nin Doğu IIllerinde HbsAg ve antïHCV seroprevalansı}

Özle m Demirpençe ${ }^{1}$, Hasan Şahin ${ }^{2}$, Alper Gümüşş3 , Ebru Kormaz ${ }^{4}$, Fatma Hakim ${ }^{4}$, Funda Uysal ${ }^{5}$

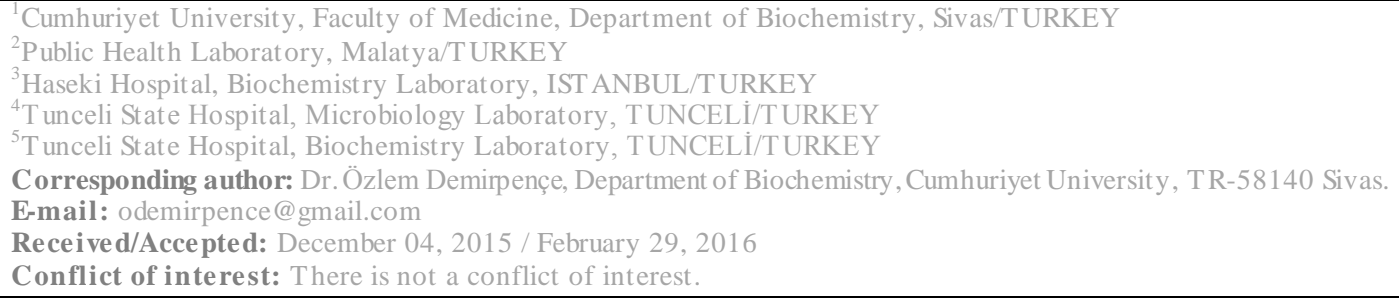

\section{SUMMARY}

Objective: The aim of this study was to investigate the seroprevalance of the Hepatitis B (HBV) and Hepatitis $\mathrm{C}(\mathrm{HCV})$ viruses among patients living in Tunceli province who had been admitted to the Tunceli State Hospital.

Method: The seropositivity rates of hepatitis B surface antigens (HBs Ag, n:3640), antibodies to hepatitis B surface antigen (anti-HBs, n:3941) and HCV antibodies (anti-HCV, n:3489) were retrospectively studied at the Tunceli StateHospital for the period between July 2013 and January 2015. Data was collected from the database of Tunceli State Hospital and analyzed using SPSS 15.00 .

Results: A total of 3640 patients tested for HBs Ag were included in this study. 154 patients (4.23 $\%$ ) were found HBsAg positive. $33(0.94 \%)$ of 3489 patients were found anti-HCV positive and $1829(46.41 \%)$ of 3941 patients were found anti-HBs positive.

Conclusions:While an earlier study had produced similar results to the current study in Tunceli province, the seroprevalence of $\mathrm{HBV}$ and HCV are still high. Therefore, community awareness should be raised through health education about transmission and prevention of HBVand HCV infections.

Keywords: Hepatitis B, Hepatitis C, Seroprevalence

ÖZET

Amaç: Bu çalışmada Tunceli ilinde yaşayıp, devlet hastanesine başvuran bireylerde Hepatit B virüsü (HBV) ve hepatit C virüsü (HCV) seroprevelansını değerlendirmek amaçland1.

Yöntem: Tunceli Devlet Hastanesinde, Hepatit B yüzey antijeni (HBs Ag, n: 3640), hepatit B yüzey antikoru (anti-HBs, n: 3941) ve HCV antikoru (anti-HCV, n: 3489) seropozitiflik oranlan retrospektif olarak, Temmuz 2013 ve Ocak 2015 arasinda incelendi. Veriler Tunceli Devlet hastanesi veri tabanından toplandıve SPSS 15.00 programı kullanılarak analiz edildi.

Bulgular: HBs Ag testi çalışılan 3640 hasta bu çalışmaya dahil edildi. 154 hasta (\%4.23) HBs Ag pozitif bulunmuștur. 3489 hastanın 33’ü (\%0.94) anti-HCV pozitif; 3941 hastanın 1829’u (46.41\%) anti-HBs pozitif bulunmuştur.

Sonuç: Daha önceki çalışmada da Tunceli ilinde benzer sonuçlar olmasına rağmen, HBV ve HCV seroprevalansı hala yüksek düzeydedir. Bu nedenle, HBV ve HCV enfeksiyonlarının bulaşması ve korunma konusunda toplumun bilinçlendirilmesi, sağlik eğitimi ile güçlendirilmelidir.

Anahtar sözcükler: Hepatit B, Hepatit C, Seroprevalans 


\section{INTRODUCTION}

$\mathrm{HBV}$ and HVC infections pose serious risks to health with significant mortality and morbidity rates in both Turkey and many other countries [1-4]. Most cases of HBV are observed in Asia-Pacific countries, while its endemicity is observed to be low in developed regions such as Northern America and Western Europe [2,4,5]. Humans are the only natural reservoir for HBV, which spreads through parenteral, perinatal, horizontal or sexual transmission (6). HBV may lead to an infection with high prevalence or may be chronic disease progression may result in cirrhosis and hepatocellular cancer [5,7]. Despite vaccination programs, there are two billion people in the world infected with HBV. Chronic HBV infection has been detected in 360 million patients [8]. Turkey is in a moderate endemicity zone in terms of HBV infection with prevalence varying between $2 \%$ and $7 \%[9,10]$.

$\mathrm{HCV}$ is a common infection throughout the world with an average frequency of $3 \%$ with 210 million infected individuals $[10,11]$. HCV accounts for $20 \%$ of acute hepatitis and $70 \%$ of chronic hepatitis cases. Since chronic infection by $\mathrm{HCV}$ can lead to cirrhosis and hepatocellular cancer (HCC), priority should be given to this infection [12,13,14]. The most common mode of transmission for HCV infection is parenteral transmission with the most affected regions being Central and Eastern Asia and Northern Africa [15,16,17].

In the current study, we determined the seroprevalance of hepatitis B and hepatitis $\mathrm{C}$ in Tunceli province and compared the results with data from earlier studies conducted in the same province and neighboring provinces. Our aim was to contribute to the countrywide data on hepatitis test results and to inform future preventive medicine measures to be adopted against HVB and $\mathrm{HCV}$ infections.

\section{MATERIALS AND METHODS}

In this complementary study, a retrospective evaluation was conducted using data from patients who had applied to the clinics of the Tunceli State Hospital with any complaint, between 24/07/2013 and 01/01/2015 and for whom hepatitis tests were ordered. The necessary approval for the study was obtained from the local ethics committee. The study covers patients from all age groups for whom $\mathrm{HBsAg}$, anti-HBs and anti-HCV serologic tests were ordered. All existing data was screened and multiple positive results from cases with repeated test orders were excluded from the study. Data from patients who had been found to be positive for the first time were verified by duplicating the laboratory tests and subsequently included in the study. Results regarded as potential false positives or negatives were excluded from the study.

The study group was divided into eight age groups covering the ranges $0-9,10-19$, 20-29, 30-39, 40-49, 50-59, 60-69 years and over 70 years. The HBsAg, anti-HBs and anti-HCV serological positivity rates of the groups were evaluated separately for men and women (Table I, II and III). The State Hospital laboratory is the only centre that studies hepatitis tests across the province, however, this study does not include the donor population, since the blood used in transfusion is obtained from the Red Crescent.

$\mathrm{HBsAg}$, anti-HBs and anti-HCV serological tests were performed on serum samples from fasting blood tests, obtained using an empty tube with gel. The serum samples were tested using the CMIA (Chemiluminescent Micro-particle Immunoassay) method on an Architect i1000 SR (Abbott, USA) device.

The resulting data from the current study was analyzed using the SPSS 15.00 (Statistical Package for Social Sciences) software. Groups with distinct data that did not conform to the normal distribution were compared using the chi square test. In a confidence interval of $95 \%$, results with $\mathrm{p}$ $<0.05$ were considered statistically significant.

\section{RESULTS}

The positivity rates of anti-HCV, $\mathrm{HBsAg}$ and anti-HBs serological tests of the study group are shown in Table I, II and III respectively with a break-down according to age and gender.

Among the 3640 individuals studied (1595 M, 2045 F),154 patients tested positive for 
HBsAg (73 M, 81 F), (4.23\%). No significant difference was found between the female and male distribution in terms of HBsAg positivity ( Chi square value $=0.83$ and $\mathrm{p}=0.36$ ).

Among the 3489 individuals studied (1584 M,1905 F), 33 individuals tested positive for HCV antibodies (13 M, 20 F), (0.94\%). Anti-HCV test positivity rates were not statistically different between the female and male distribution ( $\mathrm{Chi}$ square val$\mathrm{ue}=0.48$ and $\mathrm{p}=0.48$ ).

Among the 3941 individuals $(1750 \mathrm{M}$, $2191 \mathrm{~F})$ tested for anti-HBs, 1829 patients tested positive for anti-HBs $(860 \mathrm{M}, 969 \mathrm{~F})$ $(46.41 \%)$. This seropositivity rate includes all active, chronic and vaccinated patients. A significant difference was found between the female and male distribution in terms of anti-HBs positivity ( Chi square value $=9.45$ and $\mathrm{P}=0.002$ ).

Table I. Distribution of anti-HCV positivity by age and gender

\begin{tabular}{|lllll|}
\hline $\begin{array}{l}\text { Age } \\
\text { Groups }\end{array}$ & $\begin{array}{c}\text { Male } \\
(\%)\end{array}$ & $\begin{array}{l}\text { Female } \\
(\%)\end{array}$ & $\begin{array}{c}\text { Total } \\
(\mathrm{n})\end{array}$ & $\begin{array}{l}\text { Total } \\
(\%)\end{array}$ \\
$0-9$ & 0 & 0 & 93 & 0 \\
$10-19$ & 0 & 0 & 171 & 0 \\
$20-29$ & 0 & 0.53 & 1223 & 0.24 \\
$30-39$ & 0.71 & 0.19 & 816 & 0.37 \\
$40-49$ & 0.64 & 3.16 & 441 & 2.27 \\
$50-59$ & 0.82 & 0.58 & 295 & 0.68 \\
$60-69$ & 2.35 & 3.70 & 193 & 3.11 \\
$\geq 70$ & 5.26 & 1.61 & 257 & 3.50 \\
Total & 0.82 & 1.05 & 3489 & 0.94 \\
\hline
\end{tabular}

Table II. Distribution of HBsAg positivity by age and gender

\begin{tabular}{|lclll|}
\hline $\begin{array}{l}\text { Age } \\
\text { Groups }\end{array}$ & $\begin{array}{c}\text { Male } \\
(\%)\end{array}$ & $\begin{array}{c}\text { Female } \\
(\%)\end{array}$ & $\begin{array}{c}\text { Total } \\
(\mathrm{n})\end{array}$ & $\begin{array}{c}\text { Total } \\
(\%)\end{array}$ \\
$0-9$ & 1.64 & 2.70 & 98 & 2.04 \\
$10-19$ & 2.38 & 0 & 165 & 1.21 \\
$20-29$ & 2.28 & 1.59 & 1287 & 1.94 \\
$30-39$ & 4.91 & 2.20 & 875 & 3.08 \\
$40-49$ & 6.13 & 5.35 & 462 & 5.63 \\
$50-59$ & 11.72 & 9.94 & 309 & 10.68 \\
$60-69$ & 10.34 & 7.77 & 190 & 8.95 \\
$\geq 70$ & 5.38 & 12.1 & 254 & 8.66 \\
Total & 4.58 & 3.96 & 3640 & 4.23 \\
\hline
\end{tabular}

Table III. Distribution of anti-HBs positivity by age and gender

\begin{tabular}{|lrccc|}
\hline $\begin{array}{l}\text { Age } \\
\text { Groups }\end{array}$ & $\begin{array}{r}\text { Male } \\
(\%)\end{array}$ & $\begin{array}{c}\text { Female } \\
(\%)\end{array}$ & $\begin{array}{c}\text { Total } \\
(\mathrm{n})\end{array}$ & $\begin{array}{c}\text { Total } \\
(\%)\end{array}$ \\
$0-9$ & 60.27 & 67.41 & 281 & 63.70 \\
$10-19$ & 62.94 & 66.41 & 274 & 64.6 \\
$20-29$ & 52.04 & 46.74 & 1290 & 49.46 \\
$30-39$ & 30.58 & 31.92 & 880 & 31.48 \\
$40-49$ & 40.24 & 39.22 & 470 & 39.57 \\
$50-59$ & 46.09 & 41.11 & 308 & 43.18 \\
$60-69$ & 46.59 & 43.56 & 189 & 44.97 \\
$\geq 70$ & 64.34 & 59.17 & 249 & 61.85 \\
Total & 49.14 & 44.23 & 3941 & 46.41 \\
\hline
\end{tabular}

\section{DISCUSSION}

Hepatitis viruses are important infection factors that may follow acute, fulminant and chronic courses and lead to serious health problems. The mortality rate in malignancies caused by hepatitis virus are also high. For example, each year 600,000 people die from a liver disease associated with HBV or from HCC [18]. In addition, chronic HBV infection accounts for approximately 250,000 deaths each year and is among the leading causes of death throughout the world [19].

Today interferon therapy or immune modulators are used for treatment of HBV infection. However, these treatment methods are expensive, may not be easily tolerated and their efficacy is not at a desired level [20,21]. Vaccination is the easiest and most inexpensive method for fighting HBV and can be administered to the highest number of individuals. Newborns are vaccinated by the state free of charge in order to prevent chronic HBV infection. The prevalence of hepatitis shows that we face a significant health risk. Therefore, preventive medicine measures are still highly important with respect to HBV infection [22].

Eastern and southeastern Turkey are known to be endemic for HBV infection. Poor socio-economic living conditions and high vertical and horizontal transition were given as explanations for the high prevalence of $\mathrm{HBV}$ in studies conducted in southeastern Turkey [23]. Tunceli is an eastern province with similar socioeconomic conditions. Asan et al. found HBsAg seroprevalence to be $4.22 \%$ in a study examining hepatitis test results in 
Tunceli from the beginning to the end of 2010 [24]. In the current study, HBsAg seropositivity was found to be $4.23 \%$. This rate is almost identical to the positivity rate found in the study previously performed by Asan et. al. in the region. A comparison of data between the current study and the study conducted by Asan et al. in Tunceli province shows that the same device and method were used. The same HBsAg seropositivity rate three and a half years after the first study suggests that vaccination, preventive medicine and education activities are not sufficiently reaching the local population.

Asan et. al. found HBsAg seroprevalence to be higher in males compared to females [24]. The findings of the current study do not show a statistically significant difference in HBsAg seroprevalence between the two genders. After dividing the individuals into age groups, Asan et. al. found that HBsAg seropositivity was most prevalent in the 50-59 age group for both males and females. The current study shows that HBsAg seropositivity was highest in the 50-59 age group for males and in the over 70 age group for females. The high rate of HBsAg positivity in the over 50 age group suggests that hepatitis B active immunization should be applied with a focus on the elderly population in Tunceli.

HBsAg is a marker that has been used for nearly fifty years in the diagnosis of HBV infection [25]. Different HBsAg positivity percentages have been reported for different regions of Turkey. HBsAg positivity rates have been reported to be lower in western provinces compared to eastern provinces $[10,26]$. In Turkey, HBsAg positivity rates have been reported to be in the range of $1.3 \%$ and $13.8 \%$ and with an average of $7.6 \%$, in the population excluding blood donors [10]. In a study performed using the cluster sampling method in Diyarbakır, Batman, Mardin and Şanliurfa provinces, which are geographically close to Tunceli, HBsAg positivity was found to be $7 \%$ [27]. The HBsAg positivity rates were found to be $10 \%$ in Siirt [28], 12.6\% in Batman [29], 4.5\% in Bitlis and Tatvan [30] and $10.4 \%$ in a study in the Training and Research Hospital of Diyarbakır [26]. The HBsAg seropositivity rate found in the current study is observed to be lower com- pared to the country average as well as to the findings from other geographically close provinces.

Studies performed in Turkey have shown that anti-HBs seropositivity ranges between 20.6 and $52.3 \%$ [22,29]. The current study found anti-HBs seropositivity to be $46.41 \%$. This rate is consistent with rates that reflect Turkey in general and covers all active, chronic and vaccinated patients. $\mathrm{HCV}$ infection, which has a lower prevalence compared to $\mathrm{HBV}$, is more frequently observed in industrializing and developing countries $[26,29]$. HCV prevalence in Turkey varies between 1 to $2.4 \%$ [29,31]. $\mathrm{HCV}$ has the highest tendency to become chronic. $27 \%$ of cirrhosis and 25\% of hepatocellular carcinoma cases in the world are associated with $\mathrm{HCV}$ infection $[16,17]$. Since anti-HCV can disappear in patients who have recovered from acute hepatitis $\mathrm{C}$, the prevalence of the infection may be higher than observed in the findings [10]. In this study, the anti-HCV positivity rate was found to be $0.94 \%$, consistent with the average values of the country. A statistically significant difference was not observed in anti-HCV positivity rates among genders. An earlier study conducted in the region by Asan et al., found the anti-HCV seropositivity rate to be $0.95 \%$ [24]. The findings of the two studies are almost identical. This rate was found to be $1.9 \%$ in a study performed in Batman [29], 0.62\% in Sïrt [28] and 1.2\% in Diyarbakır [26].

\section{CONCLUSIONS}

HBV and HCV infections, for which effective and curative treatment is difficult, continue to pose public health risk in the province of Tunceli. HBV and HCV infection seropositivity rates were found to be similar across a number of studies. The results found in the current study suggest that measures against the sources of infection and training efforts have not proven sufficient in preventing these diseases. Vaccination should be prioritized to protect HBsAg positive individuals. It is necessary to screen, train and duly vaccinate family members. Likewise, protection efforts against $\mathrm{HCV}$ infection should be revisited to incorporate measures against sources of infection and routes of transmis- 
sion as well as more effective training.

\section{REFERENCES}

1. Thomas D, Zoulim F. New challenges in viral hepatitis. Gut 2012; 61(1): 1-5.

2. Edey M, Barraclough K, Johnson DW. Review article: Hepatitis B and dialysis Nephrology (Carlton). 2010; 15: 137-45.

3. Riaz $M$, Idrees $M$, Kanwal $H$, Kabir F. An overview of Triple infection with Hepatitis B, C and D viruses. Virol J 2011; 8: 368.

4. Özdemir D, Kurt H. Hepatit B Virusu Enfeksiyonlarmin Epidemiyolojisi. Tabak F, Balik İ, Tekeli E (eds). Viral Hepatit 2007. İstanbul: Viral Hepatitle Savaşım Derneği. 2007: 108-17

5. World Health Organisation 2012. Prevention \& Control of Viral Hepatitis Infection, Framework for Global Action, 2012.

6. Badur S. Ülkemizde viral hepatitlerin durumu. In: Kilıçturgay K, ed. Viral Hepatit '94. Ankara: Viral Hepatitle Savaşım Derneği,1994; pp 15-37.

7. DienctagJL, Wands JR, Isselbacher KJ. Acute hepatitis. In. Wilson JD, Braunwald E, Isselbacher KJ, PedersdorfRG, Martin JB, Fauci AS, Root RK (eds). Harrison's Principles of Internal Practice. New York: McGraw-Hill Inc, 1991, pp 13221337.

8. Shepard CW, Simard EP, Finelli L, Fiore AE, Bell BP. Hepatitis B virus infection: epidemiology and vaccination Epidemiol Rev 2006; 28: 112-25.

9. Stevens GA, Groeger J, Wiersma ST. Global epidemiology of hepatitis B virus infection: new estimates of age specific HBsAgseroprevalence and endemicity Vaccine 2012; 30(12): 2212-19.
10. Mistik R. Türkiye'de viral hepatit epidemiyolojisi yaymların irdelenmesi. Tabak F, Balık İ, Tekeli E (eds). Viral Hepatit. 1. Baskı. İstanbul: Viral Hepatitle Savaşım Derneği, 2007; pp 10-50.

11. Gacche RN, Al-Mohani SK. Seroprevalence and Risk Factors for Hepatitis C Virus Infection among General Population in Central Region of Yemen. Hepat Res Treat 2012; 2012: 689726.

12. Leblebicioğlu H. Kronik Hepatit C'de Güncel Tedavi. Ankem 2006; 20: 208-12.

13. Manns MP, McHutchison JG, Gordon SC, RustgiVK, Shiffman M, Reindollar R, Goodman ZD, Koury K, Ling M, Albrecht JK. Peginterferon alfa-2b plus ribavirin compared with interferon alfa-2a plus ribavirin for initial treatment of chronic hepatitis $\mathrm{C}$ : a randomised trial. Lancet 2001; 358: 958-65.

14. Sümer Ş, Ural $O$, Demir NA , Ural G , Balc1 M, Dikici N. Kronik Hepatit C'li Hastalarda Standart İnterferon Alfa $2 \mathrm{a}+$ Ribavirin Kombinasyonu İle Pegileinterferon Alfa $2 \mathrm{a}+$ Ribavirin Kombinasyonunun Etkinliğinin Karşılaştırılması. Viral Hepatit Dergisi 2009; 14(3): 87-90.

15. Torresi J, Johnson D, Wedemeyer H. Progress in the development of preventive and therapeutic vaccines for hepatitis $\mathrm{C}$ virus. $\mathrm{J}$ Hepatol 2011; 54: 1273-85.

16. Lavanchy D. The global burden of hepatitis C. Liver Int 2009; 29 (1): 74-81.

17. Barut ŞH, Gunal O. Dünyada ve Ülkemizde Hepatit C Epidemiyolojisi. Klimik Dergisi 2009; 22: 38-43.

18. Shepard CW, Simard EP, Finelli L, Fiore AE, Bell BP. Hepatitis B virus infection: epidemiology and vaccination. Epidemiol Rev 2006; 


\section{8: $112-125$}

19. Maynard JE. Hepatitis B: global importance and need for control. Vaccine 1990; 8(1): 18-20.

20. Coşkun Ö, Savaşçı Ü, Eyigün CP. Hepatit B Virüs enfeksiyonunda güncel tedavi yaklaşımları. Anatol J Clin Investig 2012; 6(4): 299310.

21. Maddrey WC. Hepatitis B: An important public health issue. Journal of Medical Virology 2000; 61(3): 362-366.

22. Poyrazoğlu S, Baykan Z, Naçar M, Çetinkaya F. Hepatit B ve C'li Hasta Yakılarmın Hepatitler Hakkındaki Bilgi Düzeyleri ve Risk Algiları . Viral Hepatit Dergisi 2009; 14(3): 108-115.

23. Gurol E, Saban C, Oral O, Cigdem A, Armagan A. Trends in hepatitis $\mathrm{B}$ and hepatitis $\mathrm{C}$ virus among blood donors over 16 years in Turkey. Eur J Epidemiol. 2006; 21(4): 299-305.

24. Asan A, Akbulut A, Saçar S, Turgut H. Tunceli Devlet Hastanesine başvuran kişilerde HBsAg ve Anti-HCV seroprevalansmin değerlendirilmesi. Viral HepatitDergisi 2011; 17(2): 52-6.

25. Chan HL, Thompson A, MartinotPeignoux M, Piratvisuth T, Cornberg M, BrunettoMR, Tillmann HL, Kao JH, Jia JD, Wedemeyer H, Locarnini S, Janssen HL,Marcellin P. Hepatitis $B$ surface antigen quantification: why and how to use it in 2011 - a core group report. J Hepatol. 2011; 55(5): 1121-31.

26. Kaya Ş, Baysal B, Temiz H, Karadağ Ö, Özdemir K, Bilman F. Seroprevalence of Hepatitis B and $\mathrm{C}$ among Patients Admitted to a Tertiary Hospital. Viral Hepatitis Journal 2014; 20(3): 120-4.

27. Mehmet D, Meliksah E, Serif Y, Gunay S, Tuncer O, Zeynep S. Prevelance of hepatitis B infection in the Southeastern region of Turkey: Comparison of risk factors for HBV infection in rural and urban areas. Jpn J Infect Dis 2005; 58: $15-9$.

28. Tunc N, Eraydın H, Cetinkaya E, Oduncu MK, Toy Ş. Siirt Devlet Hastanesi'ne Başvuran Hastalarda HBsAg, Anti-HBs, Anti- HCVve Anti-HIV Seroprevalansı. Viral HepatitDergisi. 2011; 17: 7-11.

29. Demirpençe Ö, Tezcan SI, Değirmen E, Mert D, Gümüş A, Celen MK. Batman Devlet Hastanesine Başvuran Kişilerde Hepatit ve HIV Serolojisinin Sonuçları Viral HepatitDergisi 2012; 18(1): 6-10.

30. Dede G, Gülen G, Paşa Ö, Çanak F, Solay AH. Bitlis ve Tatvan Devlet Hastanesi'ne Başvuran Hastalarda HBsAg, Anti-HBs, Anti-HCVve Anti-HIV Seroprevalans1. Kocatepe Tip Dergisi 2015;16:122-125.

31. Sünbül M. HCV enfeksiyonunun epidemiyolojisi ve korunma. İn:Tabak F, Balık İ, Tekeli E (eds). Viral Hepatit. 1. Bask1. Viral Hepatitle Savaşım Derneği, İstanbul. 2007: pp 208-219. 